This is an electronic version of an article that was published as: Baker, D.W., Wood, A.M., \& Kieffer, J.D. (2005). Juvenile Atlantic and shortnose sturgeons (family: Acipenseridae) have different hematological responses to acute environmental hypoxia. Physiological and Biochemical Zoology, 78(6), 916-925. DOI: $10.1086 / 432860$

Physiological and Biochemical Zoology is published by The University of Chicago Press. More information about the journal can be found at: http://www.journals.uchicago.edu/journals/pbz/about. This article can be accessed at: http://dx.doi.org/10.1086/432860. 


\section{Juvenile Atlantic and Shortnose Sturgeons (Family: Acipenseridae) Have Different Hematological Responses to Acute Environmental Hypoxia}

D. W. Baker

A. M. Wood

\section{J. D. Kieffer ${ }^{\star}$}

Department of Biology, University of New Brunswick, Saint John, P.O. Box 5050, Saint John, New Brunswick E2L 4L5, Canada

Accepted 2/25/2005; Electronically Published 9/19/2005

\section{ABSTRACT}

Experiments were conducted to determine the behavioral and physiological responses to acute hypoxic challenges in Atlantic (Acipenser oxyrinchus) and shortnose (Acipenser brevirostrum) sturgeons. We measured the ventilatory rate following a 45mmHg hypoxic challenge, as well as a variety of hematological parameters, including $\mathrm{O}_{2}$ transport and hormonal, ionic, and metabolic variables, following a 1-h exposure to either 75- or 30-mmHg hypoxic challenges. Compared to fish in normoxic conditions ( $\mathrm{PwO}_{2} 150 \mathrm{mmHg}$ ), juveniles of both species increased their ventilatory rate by approximately $40 \%$ when exposed to a 1-h challenge at $45 \mathrm{mmHg} \mathrm{PwO}_{2}$. Hematological variables (e.g., hematocrit, hemoglobin, and $\mathrm{Na}^{+}$and $\mathrm{Cl}^{-}$levels) did not change substantially following a 1-h challenge at 75 $\mathrm{mmHg} \mathrm{PwO}_{2}$. Conversely, a severe hypoxic challenge of 30 mmHg caused changes in several hematological variables (e.g., whole blood glucose and plasma cortisol and lactate levels). Most of these hematological parameters returned to prehypoxic levels within 2 h. Severe environmental hypoxia elicited the same basic pattern of response in both species; however, maximal plasma lactate levels were higher in Atlantic sturgeons, and maximal cortisol levels were higher in shortnose sturgeons. Whether these species differences are related to dissimilar hypoxia-tolerance, ecological, and/or endocrinological characteristics between these two species is not entirely clear.

\footnotetext{
*Corresponding author; e-mail: jkieffer@unbsj.ca.
}

Physiological and Biochemical Zoology 78(6):916-925 2005 (c) 2005 by The University of Chicago All rights reserved 1522-2152/2005/7806-4086\$1500

\section{Introduction}

Freshwater fish may experience periods of hypoxia resulting from either abiotic (e.g., depth, temperature) or biotic (e.g., algal blooms) factors from both natural and anthropogenic sources (McKenzie et al. 1997). Environmental hypoxia can induce many compensatory processes in fishes (Salama and Nikinmaa 1989; Fritsche and Nilsson 1993; Hochachka and Lutz 2001), which have been well described for highly sensitive (e.g., rainbow trout; Boutilier et al. 1988) and highly tolerant (e.g., African lungfish; Dunn et al. 1983) species. These compensatory mechanisms, such as increased ventilatory rate or lowered standard metabolic rate, help fish to survive both shortand long-term hypoxic episodes (Jensen et al. 1993). Typically, these mechanisms are initiated by primary endocrine (e.g., catecholamine or corticosteroid) responses (Fritsche and Nilsson 1993; Perry and Reid 1994).

The majority of research on hypoxic responses in fish has focused on teleost species, with an emphasis on salmonid species, such as rainbow trout (Fritsche and Nilsson 1993). Physiological and behavioral responses of sturgeons to environmental hypoxia have been less studied (Burggren and Randall 1978; Maxime et al. 1995). While the sturgeon family (approximately 27 species) does not exhibit the species diversity of the teleosts, it represents a group of fishes worthy of study because of its phylogenetic position. The sturgeons are migratory benthic cruisers (Bain 1997) and could be exposed to low environmental oxygen during many stages of their life history. Some responses to low oxygen in sturgeons have been investigated under laboratory conditions (e.g., oxygen uptake and transport [Burggren and Randall 1978], circulatory and respiratory effects [Maxime et al. 1995], oxygen consumption [McKenzie et al. 1997], mortality [Secor and Gunderson 1998], growth and activity [Cech and Crocker 2002]). However, our understanding of the tolerance of and subsequent responses to hypoxia is limited to certain species and thus inadequately described for many species of sturgeon. Consequently, the efficiency of hypoxia-tolerance mechanisms in these ancient fish is generally poorly understood.

Recent research from our laboratory has demonstrated that both the primary (e.g., plasma cortisol) and secondary (e.g., whole blood glucose, plasma lactate) stress responses of juvenile Atlantic and shortnose sturgeons to forced activity are small in magnitude as compared to those of many teleosts, in particular, 
salmonids (Kieffer et al. 2001; Baker et al. 2005). Reduced hematological responses to a variety of stressors have been established for some sturgeon species (e.g., handling and air exposure [Barton et al. 2000], exhaustive exercise [Kieffer et al. 2001]). However, it remains unclear whether these reduced anaerobic and stress responses are caused by a mechanistic inability of sturgeons to respond to the same degree as these teleosts (e.g., Barton et al. 2000; Kieffer et al. 2001) or by lifehistory characteristics (e.g., benthic feeding) that limit advantages associated with these responses. Environmental hypoxia may be similar to an exercise challenge (Jensen et al. 1993) in that it activates anaerobic pathways, although it does not involve handling. It has the added advantage over exercise challenges, however, that each animal receives an identical challenge. Therefore, hypoxia may be used as an effective tool to investigate the adaptive mechanisms of sturgeons.

In this study, we investigated strategies of hypoxia tolerance in two species of sturgeon. Juvenile Atlantic and shortnose sturgeons were challenged to acute environmental hypoxia (partial pressure of oxygen in water $\left[\mathrm{PwO}_{2}\right]$ of 75,45 , or 30 $\mathrm{mmHg}$ ), and the response was compared with that under normoxic conditions $\left(\mathrm{PwO}_{2} 150 \mathrm{mmHg}\right)$. In the first series, individuals of both species were challenged for $1 \mathrm{~h}$ to $45-\mathrm{mmHg}$ environmental hypoxia, and ventilatory frequencies of the fish were recorded. In the second series, individuals were exposed for $1 \mathrm{~h}$ to either 75- or 30-mmHg environmental hypoxia. These values were selected based on the responses of white sturgeon to a $58 \%$ air-saturation $\left(\approx 90 \mathrm{mmHg} \mathrm{O}_{2}\right.$ ) challenge by Cech and Crocker (2002) and a 38\% air-saturation $\left(60 \mathrm{mmHg} \mathrm{O}_{2}\right)$ challenge by Burggren and Randall (1978). The recovery process was then assessed immediately following this challenge and 1 and $2 \mathrm{~h}$ after the fish were returned to normoxic water. Thus, these levels of oxygen content were intended to simulate moderate and severe environmental hypoxic challenge to individuals and so to induce compensatory responses to hypoxia that could be monitored throughout recovery. In an effort to further understand the fundamental physiology of sturgeons, these experiments were conducted on two Acipenserid species, the Atlantic and shortnose sturgeon, which have many similar aspects of life cycle and habitat (Bain 1997), including sympatric juvenile stages in the Saint John River, New Brunswick, Canada (Giberson and Litvak 2003). Thus, we hypothesized that these two sturgeons would exhibit similar responses to acute environmental hypoxia and that these responses would reflect inherent differences between sturgeons (i.e., ancient chondrosteans) and the teleosts, which have typically been used to examine hypoxia physiology.

\section{Material and Methods}

\section{Animal Husbandry}

Juvenile $(2+$ yr of age, mean length $\approx 30 \mathrm{~cm}$, mean weight $\approx$ $100 \mathrm{~g}$ ) Atlantic (Acipenser oxyrinchus) and shortnose (Acipenser brevirostrum) sturgeons were obtained from M. K. Litvak's fishrearing facility at the University of New Brunswick, Saint John. These fish were raised from eggs originating from Saint John River sturgeon stock. Juveniles were fed $1 \%$ of their body mass daily (Corey Aquafeeds HIPRO 3.0 sinking crumble). Both species of sturgeon were acclimated in dechlorinated city water $\left(15^{\circ} \pm 1^{\circ} \mathrm{C}\right.$, water hardness $\left.\approx 60 \mathrm{mg} \mathrm{L}^{-1} \mathrm{CaCO}_{3}, \mathrm{pH} \approx 7\right)$.

\section{Environmental Hypoxia}

Aquatic environmental hypoxia was achieved by bubbling one of two mixed $\left(10 \% \mathrm{O}_{2} / 90 \% \mathrm{~N}_{2}\right.$ or $\left.4 \% \mathrm{O}_{2} / 96 \% \mathrm{~N}_{2}\right)$ gases through a vertical column (ABS pipe, 1 -m length by $8-\mathrm{cm}$ diameter) filled with aeration beads. Mixed gas was bubbled through the vertical column to achieve $50 \%$ of typical air saturation $\left(\mathrm{PwO}_{2} 75\right.$ $\mathrm{mmHg}$ ), 30\% air saturation (45 $\mathrm{mmHg}$ ), or $20 \%$ air saturation (30 mmHg). By using high-quality mixed gases and a vertical mixing column, we were able to ensure that a consistent and stable oxygen concentration was delivered to each chamber. Water entered the bottom of the column and then, while being aerated by one of the two mixed gases, flowed out of the top of the column and into the experimental chambers. Oxygen content (in $\mathrm{mg} \mathrm{L}^{-1}$ ) in water flowing to each chamber was measured using a YSI oxygen meter (model 500DO), and the values were then converted to partial pressure in millimeters of mercury $(1 \mathrm{mmHg}=1$ Torr $=0.133 \mathrm{kPa})$.

\section{Series 1: Ventilatory Response to Environmental Hypoxia}

To reduce possible dietary influences on metabolic status, fish were not fed on the day before the start of experiments (Kieffer and Tufts 1998). Fish ( $N=6$ for each species) were removed by net from holding tanks and were placed individually in clear plastic flow-through tanks (total volume $\approx 25 \mathrm{~L}$ ). Tanks were isolated from each other and supplied with air-saturated $\left(\mathrm{PwO}_{2}\right.$ $150 \mathrm{mmHg}$ ) water at $15^{\circ} \pm 1^{\circ} \mathrm{C}$ at a flow rate of $3 \mathrm{~L} \mathrm{~min}^{-1}$. Tanks were covered with black opaque plastic to prevent any visual disturbances during the experiment. Fish were held in these tanks overnight before experimentation. The next morning, fish were videotaped from above under normoxic conditions for 30 min using a Sony Digital 8 video camera. Following this, hypoxic water was introduced into the tanks such that environmental hypoxia $\left(\mathrm{PwO}_{2} 45 \mathrm{mmHg}\right)$ was achieved within $10 \mathrm{~min}$. This level of hypoxia was maintained for $1 \mathrm{~h}$, during which fish behavior was again videotaped. From the video, ventilatory beats in $1 \mathrm{~min}$ were counted at 5-min intervals throughout normoxic and hypoxic episodes and recorded as ventilation frequency in beats per minute.

\section{Series 2: Hematological Responses to Environmental Hypoxia}

Fish ( $N=8$ for each group) were randomly removed from their holding tanks and placed individually in small flow- 
through Perspex boxes (total volume $\approx 2 \mathrm{~L}$ ) similar to those described by Kieffer et al. (2001). Each box was supplied with well-oxygenated $\left(\mathrm{PwO}_{2} 150 \mathrm{mmHg}\right)$ water at $15^{\circ} \pm 1^{\circ} \mathrm{C}$ at a flow rate of $0.2 \mathrm{~L} \mathrm{~min}^{-1}$. This flow rate did not induce swimming in fish. Fish were held in these boxes for $24 \mathrm{~h}$ before blood sampling (Kieffer et al. 2001). Following this period, fish were either sampled immediately (i.e., under normoxic conditions) or subjected to a 1-h environmental hypoxic challenge at either 75 or $30 \mathrm{mmHg}$. Hypoxia was achieved (as noted above) within $5 \mathrm{~min}$ in each box and remained consistent throughout the hour as measured by a YSI oxygen meter (see "Series 1"). Neither of the hypoxic regimes induced burst swimming in fish. Fish of each species subjected to an environmental hypoxic challenge were sampled either immediately after the 1-h hypoxic exposure or following either a 1- or 2-h recovery period under normoxic conditions. Before fish were sampled, water flow to the box was suspended, and individuals were anesthetized with a buffered ( $\left.\mathrm{pH} 7 ; \mathrm{NaHCO}_{3}\right)$ tricainemethanesulphonate solution (TMS, $330 \mathrm{mg} \mathrm{L}^{-1}$ ). Once anesthetized, fish were quickly removed from their boxes and blotted dry, and the total lengths (to the nearest $\mathrm{cm}$ ) and weights (to the nearest $\mathrm{g}$ ) were recorded. Blood samples $(1 \mathrm{~mL})$ were drawn via the caudal vessels using a heparin-coated needle and syringe (Houston 1990). These blood samples were immediately treated as described below.

The experimental protocol was approved by the University of New Brunswick Animal Care Committee (permit 2-11-2001) and meets Canadian Council of Animal Care guidelines.

\section{Analytical Protocol and Techniques}

From the whole blood sample, duplicate $20-\mu \mathrm{L}$ aliquots were used to determine the total hemoglobin content (Sigma, 525$2)$. Whole blood aliquots $(2 \mu \mathrm{L})$ were used to determine the whole blood glucose concentration (Glucometer Elite, model $3903 \mathrm{E}$, Bayer). Blood samples of approximately $100 \mu \mathrm{L}$ were used for duplicate hematocrit determination (Kieffer et al. 1994). From the hemoglobin and hematocrit values, mean erythrocyte hemoglobin concentration (MEHC) was calculated using the following formula:

$$
\text { MEHC }\left(\mathrm{g} \mathrm{Hb} \mathrm{dL}^{-1}\right)=\frac{\text { hemoglobin }\left(\mathrm{g} \mathrm{dL}^{-1}\right)}{\text { hematocrit }(\%)} \times 100
$$

\section{(Houston 1990).}

The remaining sample of whole blood was transferred into a 1.5-mL centrifuge tube and centrifuged at 10,000 rpm for 4 min. A portion $(100 \mu \mathrm{L})$ of the resultant plasma was then added to $100 \mu \mathrm{L} 8 \%$ perchloric acid, mixed well, and placed in liquid nitrogen. The remaining plasma was placed into duplicate 500$\mu \mathrm{L}$ centrifuge tubes and immediately placed in liquid nitrogen. Frozen acidified plasma samples were later thawed and analyzed by spectrophotometer for lactate concentrations using the method described by Lowry and Passonneau (1972).

From one of the two nonacidified samples, osmolality (model 3300 micro-osmometer, Advanced Instruments) and chloride, sodium, and potassium concentrations (model 664 sodium/ chloride/potassium analyzer, Corning) were analyzed in duplicate. From the other nonacidified plasma sample, total protein content was assessed with either a $40-\mu \mathrm{L}$ sample (Atlantic sturgeon) or a $25-\mu \mathrm{L}$ sample (shortnose sturgeon) using a protein assay kit (541-2, Sigma). Finally, cortisol concentrations were determined from this nonacidified sample using $25-\mu \mathrm{L}$ samples with random duplicates using a radioimmunoassay cortisol kit (ImmuChem coated-tube RIA kit, ICN Biomedicals) by gamma counter.

\section{Statistical Analysis}

For all measurements, all treatment groups were analyzed for normality using the Shapiro-Wilks test and for equal variance using Levene's test. When necessary, logarithmic transformation or Taylor's power law (Elliot 1971) were used. To examine species and oxygen-level effects on ventilatory frequency, a twoway repeated-measures ANOVA was used. The effect of oxygen concentration on individual variability of ventilatory frequency was examined using a paired-sample $t$-test (Zar 1999). To examine species and recovery effects for each hypoxic challenge, two-way ANOVA (Type I fixed-effect) tests were used. A Bonferroni-adjusted Dunnet's post hoc test was used to determine where differences occurred. If the interaction term was significant $(P<0.200$; Winer 1971), a one-way ANOVA reorganizing each combination of original independent variables as a level of treatment was employed (Zar 1999) to compare treatment effects within each species and species effect within each treatment. Where assumptions of normality or variance were violated, ANOVA on ranks (Zar 1999) was used to confirm results. Alpha in all cases was 5\% $(P<0.05)$. All values are presented as mean \pm standard error. All statistical tests were performed with SigmaStat (ver. 2.03).

\section{Results}

The mean weights of Atlantic and shortnose sturgeons for all experiments were $93 \pm 3$ and $91 \pm 7$ g, respectively. The mean lengths of Atlantic and shortnose sturgeons for all experiments were $30 \pm 0.5$ and $29 \pm 1 \mathrm{~cm}$, respectively. Neither weights nor lengths were significantly different between any two groups within or between species (one-way ANOVA; $P>0.05$ for weights and lengths).

\section{Series 1: Ventilatory Response to Environmental Hypoxia}

Ventilatory frequency was not significantly different between Atlantic and shortnose sturgeons under normoxic conditions 
(97 \pm 17 and $91 \pm 7$ beats $\min ^{-1}$, respectively). An immediate, sustained ( $>1 \mathrm{~h})$, and significant $(40 \%)$ increase in ventilation frequency occurred in both species during environmental hypoxia (see Fig. 1). Ventilatory rates were not significantly different between Atlantic and shortnose sturgeons (136 \pm 6 and $136 \pm 8$ beats $\min ^{-1}$, respectively) during the challenge at 45 $\mathrm{mmHg}$. Within individuals, mean ventilatory frequency during hypoxia was significantly less variable than during normoxia ( $t$-test, $P<0.05)$.

Series 2: Hematological Responses to Environmental Hypoxia

Plasma cortisol concentrations increased significantly immediately following 1 -h $30-\mathrm{mmHg}$ hypoxic challenges in both Atlantic and shortnose sturgeons $(21.9 \pm 3.7$ and $85.9 \pm 29.0$ ng $\mathrm{mL}^{-1}$, respectively; one-way ANOVA; see Fig. 2). These elevations were transient, since cortisol levels returned to prehypoxic levels after $2 \mathrm{~h}$ of recovery under normoxic conditions. Immediately following the more severe hypoxic challenge, cortisol concentrations were about four times higher and showed greater variability about the mean in shortnose sturgeons than in Atlantic sturgeons (two-way ANOVA, species $P<0.001$ ). Mean plasma cortisol concentrations were not significantly elevated following a 75-mmHg hypoxic challenge in either species (see Fig. 2).

Mean blood glucose levels were also significantly elevated in both species following a 30-mmHg hypoxic challenge (see Fig. $3)$. Atlantic sturgeon whole blood glucose levels were elevated $\left(6.3 \pm 0.3 \mathrm{mmol} \mathrm{L}^{-1}\right)$ immediately following this hypoxic challenge compared to normoxic levels $\left(3.8 \pm 0.2 \mathrm{mmol} \mathrm{L}^{-1}\right)$ and remained elevated $2 \mathrm{~h}$ later (one-way ANOVA, $P<0.001$ ). Blood glucose levels in shortnose sturgeons were significantly elevated $\left(8.2 \pm 1.1 \mathrm{mmol} \mathrm{L}^{-1}\right)$ from normoxic levels $(3.6 \pm$ $0.2 \mathrm{mmol} \mathrm{L}^{-1}$ ) after $1 \mathrm{~h}$ of recovery under normoxic conditions (one-way ANOVA, $P<0.001$ ) but not after $2 \mathrm{~h}$. Whole blood glucose concentrations were not modified by a 1 -h exposure to moderate $\left(\mathrm{PwO}_{2} 75 \mathrm{mmHg}\right)$ hypoxia in either species (see Fig. 3).

Plasma lactate concentrations were elevated in Atlantic $\left(4.1 \pm 0.6 \mathrm{mmol} \mathrm{L}^{-1}\right.$; one-way ANOVA, $\left.P<0.001\right)$ and shortnose $\left(2.7 \pm 0.2 \mathrm{mmol} \mathrm{L}{ }^{-1}\right.$; one-way ANOVA, $\left.P<0.001\right)$ sturgeons immediately following a 1-h $30-\mathrm{mmHg}$ hypoxic challenge (see Fig. 4). These elevations were transient, however, and values had returned to prehypoxic levels by $2 \mathrm{~h}$ into the recovery period. While the patterns of elevation were similar between species following a $30-\mathrm{mmHg}$ hypoxic challenge, overall lactate concentration was higher in Atlantic sturgeons (two-way ANOVA, species $P<0.001)$. Plasma lactate concentrations were not elevated following a $1-\mathrm{h} 75-\mathrm{mmHg}$ challenge in either species (one-way ANOVA, $P<0.05$; see Fig. $4 B$ ).

Mean hematocrit, mean hemoglobin concentration, and mean erythrocytic hemoglobin concentration did not signifi-

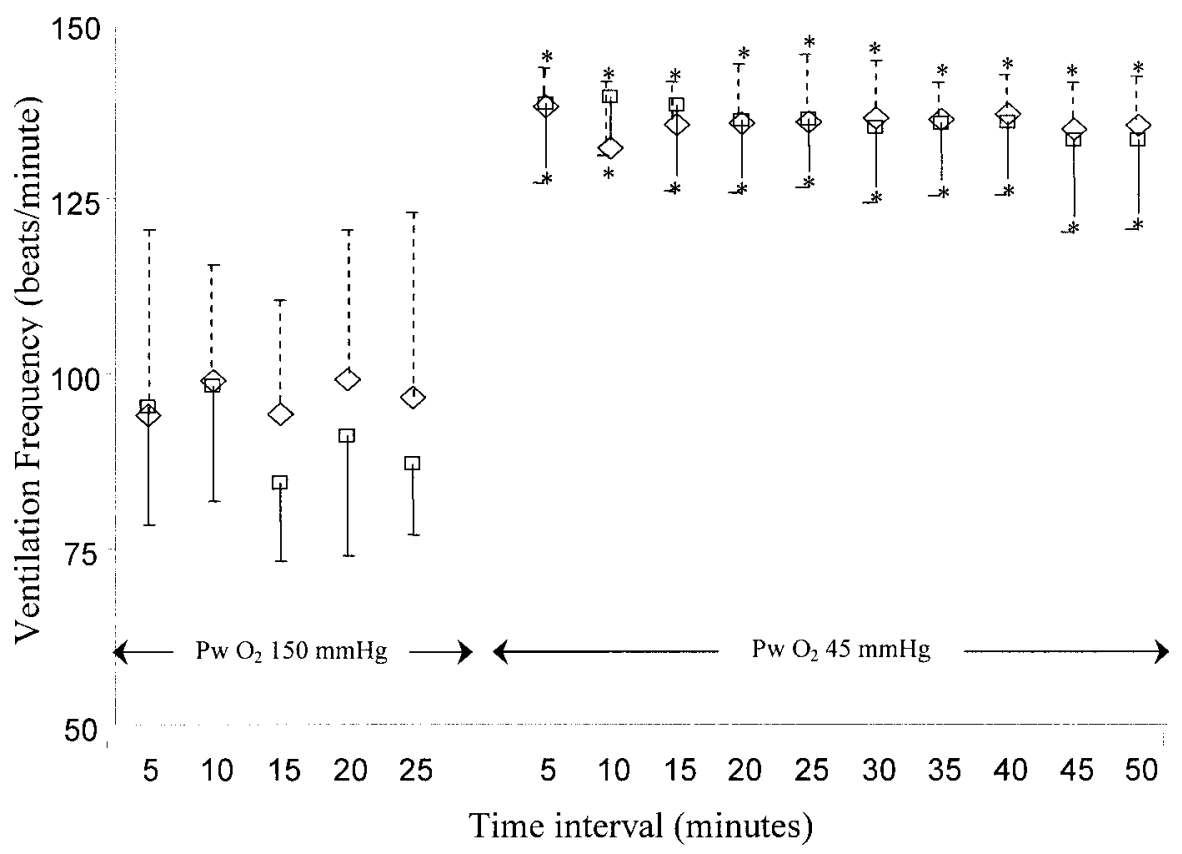

Figure 1. Mean $( \pm \mathrm{SEM})$ interval $(5 \mathrm{~min})$ gill ventilation frequency during environmental normoxia $\left(\mathrm{PwO}_{2} 150 \mathrm{mmHg}\right)$ and acute environmental hypoxia $\left(\mathrm{PwO}_{2} 45 \mathrm{mmHg}\right.$ ) in beats per minute of Atlantic (diamonds) and shortnose (squares) sturgeons. Dotted error bars above symbols signify Atlantic sturgeon SEM; solid error bars below symbols signify shortnose sturgeon SEM. Asterisks denote significant differences from normoxic levels within a species. $N=6$ for each species. 
A.

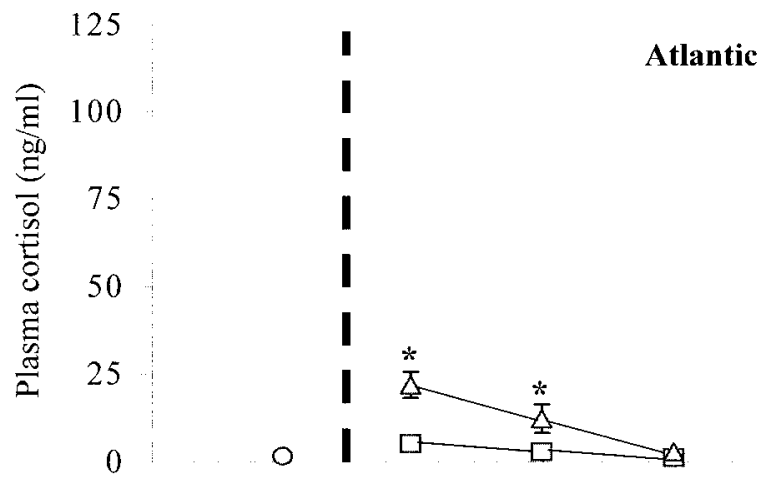

B.

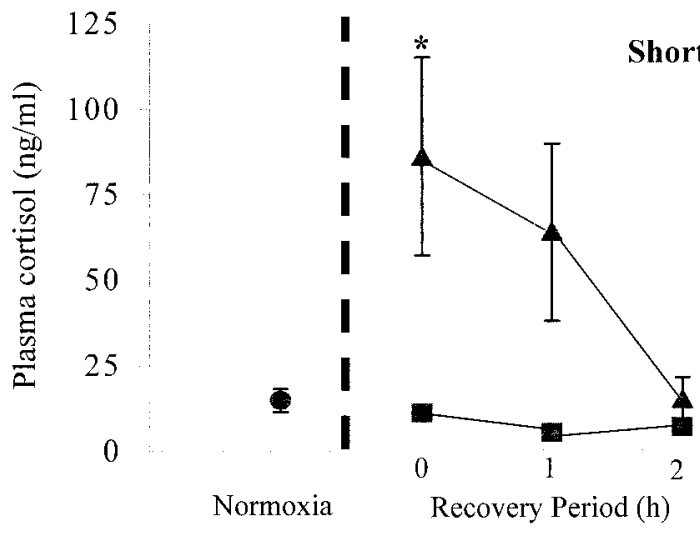

Figure 2. Mean ( \pm SEM) plasma cortisol concentration of Atlantic ( $A$; open symbols) and shortnose (B; filled symbols) sturgeons under normoxic conditions $\left(\mathrm{PwO}_{2} 150 \mathrm{mmHg}\right.$; circles $)$, immediately following $(0$ $\mathrm{h}$ ) the hypoxic challenges, and 1 and $2 \mathrm{~h}$ after return to normoxic water. The dotted line signifies the 1-h hypoxic challenge, squares represent the recovery pattern following a $75-\mathrm{mmHg}$ hypoxic challenge, and triangles represent the recovery pattern following a 30$\mathrm{mmHg}$ hypoxic challenge. Asterisks denote significant differences from normoxic levels within a species. $N=8$ for each treatment group.

cantly increase following $1 \mathrm{~h}$ of either $75-\mathrm{mmHg}$ or $30-\mathrm{mmHg}$ environmental hypoxia within either species (one-way ANOVA, $P>0.05$; see Tables 1,2 ). Similarly, plasma osmolality and chloride, sodium, and potassium levels were not affected substantially by environmental hypoxia in either species (see Tables 3 , $4)$.

\section{Discussion}

The primary constraint for many fish species under hypoxic conditions is the maintenance of respiratory homeostasis (Maxime et al. 2000). Many studies on fish have concentrated on describing compensatory responses to environmental hypoxia and subsequently developing models to explain the mechanistic character of this response (Holeton and Randall 1967; Hughes 1981; Fritsche and Nilsson 1993; Perry and Gilmour 1999; Hochachka and Lutz 2001). With few exceptions (e.g., Nonnotte et al. 1993; Maxime et al. 1995; McKenzie et al. 1997; Parsons and Carlson 1998), research on hypoxia in fish has been limited to teleosts (Maxime et al. 2000).

\section{Ventilatory Response}

Increased ventilatory response is common in teleosts exposed to hypoxia (Steffensen et al. 1982; Nonnotte et al. 1993; Maxime et al. 2000; Furimsky et al. 2003). Hyperventilation may be an important strategy for sturgeons during hypoxia. Ventilation frequencies during normoxic conditions were similar to (Crocker and Cech 2002) or slightly higher than (Burggren and Randall 1978; Cech and Crocker 2002) values that have been recorded for white sturgeons. In this study, both species of sturgeon maintained an elevated (compared to normoxic levels) ventilation frequency throughout exposure to a hypoxic challenge at $45 \mathrm{mmHg} \mathrm{PwO}_{2}$. Other sturgeon species have exhibited a similar response to hypoxia (Acipenser baeri [Maxime et al. 1995], Acipenser naccarii [McKenzie et al. 1995], Acipenser transmontanus [Crocker and Cech 2002]). Within individuals, variability in the mean ventilation frequency was significantly less during the hypoxic challenge than during normoxic con-

A.

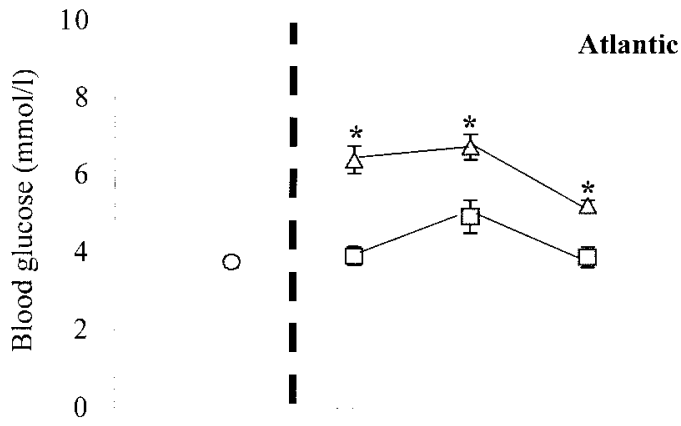

B.

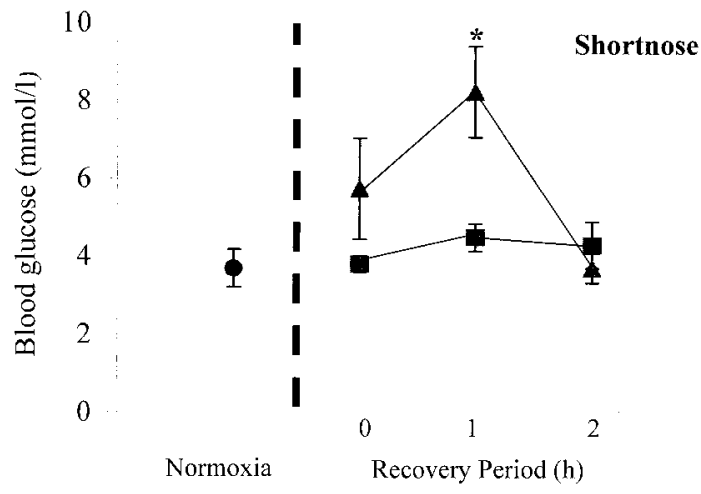

Figure 3. Mean ( \pm SEM) whole blood glucose concentration of Atlantic ( $A$; open symbols) and shortnose ( $B$; filled symbols) sturgeons under normoxic conditions $\left(\mathrm{PwO}_{2} 150 \mathrm{mmHg}\right.$; circles $)$, immediately following $(0 \mathrm{~h})$ the hypoxic challenges, and 1 and $2 \mathrm{~h}$ after return to normoxic water. Other details as in Figure 2. 
A.

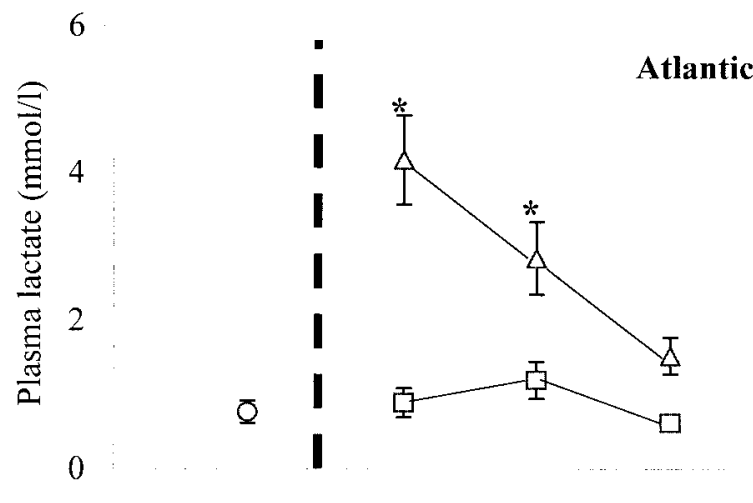

B.

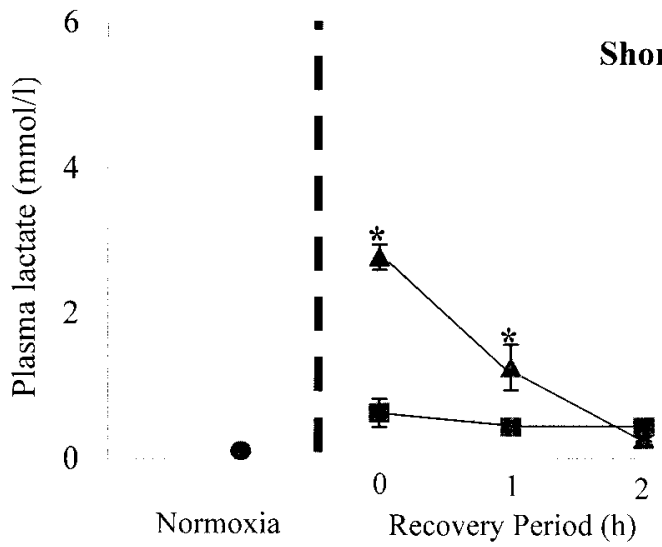

Figure 4. Mean $( \pm$ SEM) plasma lactate concentration of Atlantic $(A$; open symbols) and shortnose (B; filled symbols) sturgeons under normoxic conditions $\left(\mathrm{PwO}_{2} 150 \mathrm{mmHg}\right.$; circles $)$, immediately following $(0$ $\mathrm{h})$ the hypoxic challenges, and 1 and $2 \mathrm{~h}$ after return to normoxic water. Other details as in Figure 2.

ditions. Although sturgeons are known to be intermittent breathers under resting conditions (Nonnotte et al. 1993), our results (confirmed by visual observation) indicate that ventilation during hypoxia becomes continuous, a result similar to what has been demonstrated in carp, Cyprinus carpio (Glass et al. 1991). Other studies have shown ventilation amplitude and volume increases in sturgeons exposed to hypoxic challenges (Maxime et al. 1995; McKenzie et al. 1995). Although ventilation amplitude and volume were not measured in the current study, it appears that a ventilatory response, overall, may be a powerful mechanism to compensate for low environmental oxygen in sturgeons.

\section{Cortisol and Glucose Response}

Environmental hypoxia can elicit a primary stress response manifested as a pronounced rise in circulating cortisol levels (Anderson et al. 1991; Barton et al. 2000); however, the extent of this elevation and associated recovery period is highly variable (Mommsen et al. 1999). While no cortisol response oc- curred in either species following a $75-\mathrm{mmHg}$ hypoxic challenge, both juvenile Atlantic and shortnose sturgeons had elevated cortisol levels following $1 \mathrm{~h}$ of a $30-\mathrm{mmHg}$ hypoxic challenge. With normoxia reestablished, clearance of excess plasma cortisol in both species occurred within $2 \mathrm{~h}$. The magnitude of the cortisol increases following severe hypoxia in Atlantic and shortnose sturgeons was similar to values for sturgeons exposed to other stressors (Maxime et al. 1995; Barton et al. 2000; Belanger et al. 2001; Cech and Crocker 2002) but low compared to values for some teleost species (see values in Perry and Gilmour 1999). In addition, it is possible that these two species have different capacities for cortisol response. Shortnose sturgeons had higher (about four times) and more variable posthypoxia cortisol levels than Atlantic sturgeons immediately following $1 \mathrm{~h}$ of severe hypoxia. This trend was similar to the response following a forced-exercise challenge in Atlantic and shortnose sturgeons (Baker et al. 2005). Taken together, it appears that there are some mechanistic differences in cortisol induction or release between these two sturgeon species.

Blood glucose was also elevated following severe hypoxia in both species of sturgeon. However, the greatest glucose elevation measured was substantially lower than levels that have been observed in teleosts during hypoxia (e.g., McDonald and Milligan 1992). This moderate response of blood glucose to stress in sturgeons has been noted in numerous studies (Nonnotte et al. 1993; Maxime et al. 1995; Cataldi et al. 1998; Barton et al. 2000; Belanger et al. 2001; Lankford et al. 2003; Baker et al. 2005). Low blood glucose levels suggest that the metabolic rate of sturgeons is also low; this characteristic of sturgeon physiology may reduce the need for costly adaptations to compensate for low-oxygen episodes.

\section{Oxygen Transport and Anaerobic Response}

Resting hemoglobin and hematocrit levels in sturgeons are low compared to those of some teleosts (Wilkie et al. 1997; Leonard and McCormick 1999; Gallaugher et al. 2001; Baker et al. 2005), suggesting relatively low oxygen-transport capacity. In this study, juvenile Atlantic and shortnose sturgeons exposed to environmental hypoxia did not increase hematocrit or hemoglobin concentration. Some teleost species with relatively small increases in hemoglobin concentration in response to hypoxia have hemoglobin with a high binding affinity for oxygen (e.g., carp, $\mathrm{P}_{50} \approx 3.8 \mathrm{mmHg}$ at blood $\mathrm{pH}$ of 8.1; Brauner et al. 2001), but some evidence indicates that this may not be the case for sturgeons $\left(\mathrm{P}_{50} \approx 15 \mathrm{mmHg}\right.$ at blood $\mathrm{pH}$ of 8.2 ; Crocker and Cech 1998). The lack of hemoglobin and hematocrit increases in Atlantic and shortnose sturgeons as hypoxia-compensation responses is not likely to indicate a reduced catecholamine response in sturgeons, since Maxime et al. (1995) detected large increases in epinephrine and norepinephrine in Siberian sturgeons exposed to $30 \mathrm{~min}$ of graded hypoxia (ending at 10 
Table 1: Hematocrit, hemoglobin, and MEHC in Atlantic sturgeons under normoxic conditions, immediately following a hypoxic challenge, and 1 and $2 \mathrm{~h}$ after return to normoxia

\begin{tabular}{lccc}
\hline Conditions & Hematocrit $(\%)$ & Hemoglobin $\left(\mathrm{g} \mathrm{dL}^{-1}\right)$ & $\mathrm{MEHC}\left(\mathrm{g} \mathrm{Hb} \mathrm{dL}^{-1}\right)$ \\
\hline $\begin{array}{l}\text { Normoxia }\left(\mathrm{PwO}_{2} 150 \mathrm{mmHg}\right) \\
\text { 75-mmHg hypoxic challenge: }\end{array}$ & $28.0 \pm 1.3$ & $5.5 \pm .4$ & $19 \pm 1$ \\
$0 \mathrm{~h}$ & $28.8 \pm 1.0$ & $5.5 \pm .2$ & $19 \pm 1$ \\
$1 \mathrm{~h}$ & $26.8 \pm 1.3$ & $4.7 \pm .3$ & $18 \pm 1$ \\
$2 \mathrm{~h}$ & $28.0 \pm 1.1$ & $6.0 \pm .3$ & $22 \pm 1$ \\
$30-\mathrm{mmHg}$ hypoxic challenge: & & & $19 \pm 1$ \\
$0 \mathrm{~h}$ & $29.6 \pm 1.7$ & $5.9 \pm .4$ & $20 \pm 1$ \\
$1 \mathrm{~h}$ & $26.2 \pm 1.4$ & $5.3 \pm .4$ & $19 \pm 1$ \\
$2 \mathrm{~h}$ & $29.2 \pm .5$ & $5.5 \pm .1$ & \\
\hline
\end{tabular}

Note. Data are presented as mean \pm SEM Hypoxic challenges were $1 \mathrm{~h}$ in duration. Times immediately following a challenge and 1 and $2 \mathrm{~h}$ after fish were returned to normoxic water are indicated by $0 \mathrm{~h}, 1 \mathrm{~h}$, and $2 \mathrm{~h}$, respectively. MEHC = mean erythrocyte hemoglobin concentration.

$\mathrm{mmHg}$ ). Regardless, because oxygen transport does not increase, other responses must compensate for reduced oxygen levels.

Cellular hypoxia typically causes the activation of anaerobic metabolism in fish (Maxime et al. 2000). In this study, both species of sturgeon had significant plasma lactate elevations after a 30-mmHg hypoxic challenge, followed by a rapid (within $2 \mathrm{~h}$ ) return to prehypoxic levels. Sturgeons exposed to stressors generally experience small lactate increases in both plasma and white muscle (Maxime et al. 1995; Barton et al. 2000; Belanger et al. 2001; Kieffer et al. 2001; Baker et al. 2005), which suggests that sturgeons may not rely heavily on anaerobic pathways. Lactate accumulations measured in this study were similar to accumulations reported for some benthic fish exposed to hypoxia (e.g., turbot; Maxime et al. 2000) but are considerably lower than those noted for species of teleosts (rainbow trout [Dunn and Hochachka 1987], bass [Furimsky et al. 2003]). Upregulation of anaerobic metabolism may be related to resting metabolic rate; thus, low lactate levels would support the hypothesis of a low metabolic rate for sturgeons.

As hypoxia persists, osmotic and ionic redistribution may occur, typically because of acidosis associated with activation of anaerobic metabolism (McDonald and Milligan 1992). In this study, osmolality and sodium, chloride, and potassium concentrations did not change following hypoxia. Taken together with lactate dynamics, these results suggest that anaerobic metabolism does not significantly contribute to the energy budget of sturgeons exposed to these levels of hypoxia.

In conclusion, these results indicate that sturgeons are able to resist acute environmental hypoxia solely through hyperventilation. However, the effectiveness of this response becomes less certain as the degree and duration of hypoxic challenge increases. For example, when sturgeons are exposed to deep hypoxia $\left(\mathrm{PwO}_{2}<30 \mathrm{mmHg}\right)$, ventilation frequencies (Maxime et al. 1995; A. M. Wood, J. D. Kieffer, and D. W. Baker, unpublished data), oxygen consumption (Burggren and Randall

Table 2: Hematocrit, hemoglobin, and MEHC in shortnose sturgeons under normoxic conditions, immediately following a hypoxic challenge, and 1 and $2 \mathrm{~h}$ after return to normoxia

\begin{tabular}{lccc}
\hline Conditions & Hematocrit $(\%)$ & Hemoglobin $\left(\mathrm{g} \mathrm{dL}^{-1}\right)$ & $\mathrm{MEHC}\left(\mathrm{g} \mathrm{Hb} \mathrm{dL}^{-1}\right)$ \\
\hline $\begin{array}{l}\text { Normoxia }\left(\mathrm{PwO}_{2} 150 \mathrm{mmHg}\right) \\
\text { 75-mmHg hypoxic challenge: }\end{array}$ & $28.8 \pm 1.9$ & $5.9 \pm .4$ & $21 \pm 2$ \\
$0 \mathrm{~h}$ & $27.3 \pm 1.2$ & $5.4 \pm .2$ & $20 \pm 1$ \\
$1 \mathrm{~h}$ & $24.5 \pm 1.2$ & $4.9 \pm .2$ & $20 \pm 1$ \\
$2 \mathrm{~h}$ & $25.3 \pm 1.2$ & $5.8 \pm .3$ & $20 \pm 1$ \\
$30-\mathrm{mmHg}$ hypoxic challenge: & & & $20 \pm 1$ \\
$0 \mathrm{~h}$ & $25.4 \pm 1.5$ & $5.2 \pm .3$ & $20 \pm 1$ \\
$1 \mathrm{~h}$ & $26.3 \pm 1.2$ & $5.2 \pm .3$ & $22 \pm 1$ \\
$2 \mathrm{~h}$ & $27.4 \pm 1.9$ & $5.8 \pm .3$ & \\
\hline
\end{tabular}

Note. Data are presented as mean \pm SEM Hypoxic challenges were $1 \mathrm{~h}$ in duration. Times immediately following a challenge and 1 and $2 \mathrm{~h}$ after fish were returned to normoxic water are indicated by $0 \mathrm{~h}, 1 \mathrm{~h}$, and $2 \mathrm{~h}$, respectively. MEHC = mean erythrocyte hemoglobin concentration. 
Table 3: Plasma osmolality and chloride, sodium, and potassium concentrations in Atlantic sturgeons under normoxic conditions, immediately following a hypoxic challenge, and 1 and $2 \mathrm{~h}$ after return to normoxia

\begin{tabular}{|c|c|c|c|c|}
\hline Conditions & $\begin{array}{l}\text { Osmolality } \\
\left(\mathrm{mOsm} \mathrm{kg}^{-1}\right)\end{array}$ & $\begin{array}{l}\text { Chloride } \\
\text { Concentration } \\
\left(\text { meq L }^{-1}\right)\end{array}$ & $\begin{array}{l}\text { Sodium } \\
\text { Concentration } \\
\left(\text { meq L L }^{-1}\right)\end{array}$ & $\begin{array}{l}\text { Potassium } \\
\text { Concentration } \\
\left(\mathrm{meq} \mathrm{L}^{-1}\right)\end{array}$ \\
\hline Normoxia $\left(\mathrm{PwO}_{2} 150 \mathrm{mmHg}\right)$ & $273 \pm 7$ & $120 \pm 2.5$ & $134 \pm 3$ & $2.27 \pm .13$ \\
\hline \multicolumn{5}{|l|}{ 75-mmHg hypoxic challenge: } \\
\hline $0 \mathrm{~h}$ & $268 \pm 3$ & $119 \pm 1$ & $138 \pm 2$ & $2.14 \pm .14$ \\
\hline $1 \mathrm{~h}$ & $274 \pm 5$ & $117 \pm 1$ & $137 \pm 1$ & $2.18 \pm .13$ \\
\hline $2 \mathrm{~h}$ & $257 \pm 4$ & $119 \pm 1$ & $136 \pm 1$ & $2.28 \pm .16$ \\
\hline \multicolumn{5}{|l|}{ 30-mmHg hypoxic challenge: } \\
\hline $0 \mathrm{~h}$ & $279 \pm 5$ & $117 \pm 1$ & $136 \pm 1$ & $2.85 \pm .14$ \\
\hline $1 \mathrm{~h}$ & $283 \pm 5$ & $118 \pm 1$ & $138 \pm 1$ & $2.44 \pm .10$ \\
\hline $2 \mathrm{~h}$ & $267 \pm 3$ & $119 \pm 1$ & $138 \pm 1$ & $2.23 \pm .11$ \\
\hline
\end{tabular}

Note. Data are presented as mean \pm SEM. Hypoxic challenges were $1 \mathrm{~h}$ in duration. Times immediately following a challenge and 1 and $2 \mathrm{~h}$ after fish were returned to normoxic water are indicated by $0 \mathrm{~h}, 1 \mathrm{~h}$, and $2 \mathrm{~h}$, respectively.

1978; Cech and Crocker 2002), and activity levels (Cech and Crocker 2002) may decrease. Recent research on Atlantic sturgeons in our laboratory also indicates that anaerobic metabolism becomes more important as hypoxic level increases (A. M. Wood, J. D. Kieffer, and D. W. Baker, unpublished data). In addition, following hypoxic episodes, sturgeons show a lack of an oxygen debt (Burggren and Randall 1978; Maxime et al. 1995). Moreover, the resting metabolic rate (Maxime et al. 1995; Kieffer et al. 2001; Cech and Crocker 2002) and blood glucose (Maxime et al. 1995; Barton et al. 2000) and hemoglobin levels of sturgeons under normoxic conditions are low compared to those of many teleosts, suggesting that sturgeons might be able to reduce their metabolic rates to offset limited oxygen availability.

These two species exhibit different magnitudes of lactate and cortisol increases following severe environmental hyp- oxia. The higher plasma lactate levels noted for Atlantic sturgeons suggest that juvenile Atlantic sturgeons may activate anaerobic metabolism more readily than shortnose sturgeons or have less efficient lactate-clearance mechanisms. Greater cortisol response indicates that juvenile shortnose sturgeons may have higher endocrine capacity or lower sensitivity to cortisol. This difference may be related to phylogenetic position and so could reflect on the evolutionary history of these two species. However, the link between cortisol and evolutionary history is not fully understood. The two species in this study were reared under identical conditions; therefore, these specific physiological differences may be results of lifehistory characteristics unique to each species, though many aspects of the ecology of these two species are similar. The physiological and biochemical origin of differences between

Table 4: Plasma osmolality and chloride, sodium, and potassium concentrations in shortnose sturgeons under normoxic conditions, immediately following a hypoxic challenge, and 1 and $2 \mathrm{~h}$ after return to normoxia

\begin{tabular}{lcccc}
\hline & $\begin{array}{l}\text { Osmolality } \\
\left(\mathrm{mOsm} \mathrm{kg}^{-1}\right)\end{array}$ & $\begin{array}{l}\text { Chloride } \\
\text { Concentration } \\
\left(\mathrm{meq} \mathrm{L}^{-1}\right)\end{array}$ & $\begin{array}{l}\text { Sodium } \\
\text { Concentration } \\
\left(\mathrm{meq} \mathrm{L}^{-1}\right)\end{array}$ & $\begin{array}{l}\text { Potassium } \\
\text { Concentration } \\
\left(\mathrm{meq} \mathrm{L}^{-1}\right)\end{array}$ \\
\hline $\begin{array}{l}\text { Normoxia }\left(\mathrm{PwO}_{2} 150 \mathrm{mmHg}\right) \\
75-\mathrm{mmHg} \text { hypoxic challenge: }\end{array}$ & $253 \pm 4$ & $112 \pm 1$ & $129 \pm 1$ & $2.45 \pm .1$ \\
$0 \mathrm{~h}$ & $252 \pm 4$ & $112 \pm 1$ & $128 \pm 1$ & $2.51 \pm .09$ \\
$1 \mathrm{~h}$ & $250 \pm 4$ & $112 \pm 1$ & $130 \pm 1$ & $2.51 \pm .15$ \\
$2 \mathrm{~h}$ & $255 \pm 3$ & $113 \pm 1$ & $130 \pm 1$ & $2.69 \pm .14$ \\
30 -mmHg hypoxic challenge: & $253 \pm 3$ & $112 \pm 2$ & $129 \pm 1$ & $2.76 \pm .14$ \\
$0 \mathrm{~h}$ & $255 \pm 1$ & $107 \pm 2$ & $130 \pm 2$ & $2.57 \pm .20$ \\
$1 \mathrm{~h}$ & $254 \pm 4$ & $108 \pm 2$ & $129 \pm 2$ & $2.43 \pm .124$ \\
\hline $\mathrm{h}$ & & & & \\
\hline
\end{tabular}

Note. Data are presented as mean \pm SEM. Hypoxic challenges were $1 \mathrm{~h}$ in duration. Times immediately following a challenge and 1 and $2 \mathrm{~h}$ after fish were returned to normoxic water are indicated by $0 \mathrm{~h}, 1 \mathrm{~h}$, and $2 \mathrm{~h}$, respectively. 
species in this ancient and robust family is worthy of continued study.

\section{Acknowledgments}

This research was supported by a discovery grant to J.D.K. and an undergraduate student research fellowship to A.M.W., both from the Natural Sciences and Engineering Research Council of Canada. Dr. M. Litvak provided the fish for this study. Thanks also to the University of New Brunswick School of Graduate Studies and the Canadian Society of Zoologists for travel awards to D.W.B.

\section{Literature Cited}

Anderson D.E., S.D. Reid, T.W. Moon, and S.F. Perry. 1991. Metabolic effects associated with chronically elevated cortisol in rainbow trout (Oncorhynchus mykiss). Can J Fish Aquat Sci 48:1811-1817.

Bain M.B. 1997. Atlantic and shortnose sturgeons of the Hudson River: common and divergent life history attributes. Environ Biol Fish 48:347-358.

Baker D.W., A.M. Wood, M.K. Litvak, and J.D. Kieffer. 2005. Haematology of juvenile Acipenser oxyrinchus and Acipenser brevirostrum at rest and following forced activity. L Fish Biol 66:208-221.

Barton B.A., H. Bollig, B.L. Hauskins, and C.R. Jansen. 2000. Juvenile pallid (Scaphirhynchus albus) and hybrid pallid $\times$ shovelnose $(S$. albus $\times$ platorynchus $)$ sturgeons exhibit low physiological responses to acute handling and severe confinement. Comp Biochem Physiol 126A:125-134.

Belanger J.M, J.H. Son, K.D. Laugero, G.P. Moberg, S.I. Doroshov, S.E. Lankford, and J.J. Cech Jr. 2001. Effects of shortterm management stress and ACTH injections on plasma cortisol levels in cultured white sturgeon, Acipenser transmontanus. Aquaculture 203:165-176.

Boutilier R.G., G. Dobson, U. Hoeger, and D.J. Randall. 1988. Acute exposure to graded levels of hypoxia in rainbow trout (Salmo gairdneri): metabolic and respiratory adaptations. I Respir Physiol 71:69-82.

Brauner C.J., T. Wang, A.L. Val, and F.B. Jensen. 2001. Nonlinear release of Bohr protons with haemoglobin-oxygenation in the blood of two teleost fishes; carp (Cyprinus carpio) and tampaqui (Colossoma macropomum). Fish Physiol Biochem 24: 97-104.

Burggren W.W. and D.J. Randall. 1978. Oxygen uptake and transport during hypoxic exposure in the sturgeon Acipenser transmontanus. Respir Physiol 34:171-183.

Cataldi E., P. Di Marco, A. Mandich, and S. Cataudella. 1998. Serum parameters of Adriatic sturgeon Acipenser naccarii (Pisces: Acipenseriformes): effects of temperature and stress. Comp Biochem Physiol 121A:351-354.
Cech J.J., Jr., and C.E. Crocker. 2002. Physiology of sturgeon: effects of hypoxia and hypercapnia. I Appl Ichthyol 18:320324.

Crocker C.E. and J.J. Cech. 1998. Effects of hypercapnia on blood-gas and acid-base status in the white sturgeon, Acipenser transmontanus. L Comp Physiol B 198:50-60.

- 2002. The effects of dissolved gases on oxygen consumption rate and ventilation frequency in white sturgeon, Acipenser transmontanus. LAppl Ichthyol 18:338-340.

Dunn J.F. and P.W. Hochachka. 1987. Turnover rates of glucose and lactate in rainbow trout during acute hypoxia. Can J Zool 65:1144-1148.

Dunn J.F., P.W. Hochachka, W. Davison, and M. Guppy. 1983. Metabolic adjustments to diving and recovery in the African lungfish. Am I Physiol 245:R651-R657.

Elliot J.M. 1971. Some Methods for the Statistical Analysis of Samples of Benthic Invertebrates. Freshwater Biol Assoc Sci Publ 25.

Fritsche R. and S. Nilsson. 1993. Cardiovascular and ventilatory control during hypoxia. Pp. 180-206 in J.C. Rankin and F.B. Jensen, eds. Fish Ecophysiology. Chapman \& Hall, London.

Furimsky M., S.J. Cooke, C.D. Suski, Y. Wang, and B.L. Tufts. 2003. Respiratory and circulatory responses to hypoxia in largemouth bass and smallmouth bass: implications for "liverelease" angling tournaments. Trans Am Fish Soc 132:10651075.

Gallaugher P.E., H. Thorarensen, A. Kiessling, and A.P. Farrell. 2001. Effects of high intensity exercise training on cardiovascular function, oxygen uptake, internal oxygen transport and osmotic balance in chinook salmon (Oncorhynchus tshawytscha) during critical swimming speed. L Exp Biol 204: 2861-2872.

Giberson A.V. and M.K. Litvak. 2003. Effect of feeding frequency on growth, food conversion efficiency, and meal size of juvenile Atlantic and shortnose sturgeon. N Am I Aquacult 65:99-105.

Glass M.L., F.T. Rantin, R.M.M. Verzola, M.N. Fernandes, and A.L. Kalinin. 1991. Cardio-respiratory synchronization and myocardial function in hypoxic carp, Cyprinus carpio L. I Fish Biol 39:143-149.

Hochachka P.W. and P.L. Lutz. 2001. Mechanism, origin, and evolution of anoxia tolerance in animals. Comp Biochem Physiol 130B:435-459.

Holeton G.F. and D.J. Randall. 1967. The effect of hypoxia upon the partial pressure of gases in the blood and water afferent and efferent to the gills of rainbow trout. I Exp Biol 46:317327.

Houston A.H. 1990. Blood and circulation. Pp. 273-322 in C.B. Schreck and P.B. Moyle, eds. Methods for Fish Biology. American Fisheries Society, Bethesda, MD.

Hughes G.M. 1981. Fish gills: past, present and future. Biol Bull India 3:69-87.

Jensen F.B., M. Nikinmaa, and R.E. Weber. 1993. Environmental 
perturbations of oxygen transport in teleost fishes: causes, consequences and compensations. Pp. 161-179 in J.C. Rankin and F.B. Jensen, eds. Fish Ecophysiology. Chapman \& Hall, London.

Kieffer J.D., S. Currie, and B.L. Tufts. 1994. Effects of environmental temperature on the metabolic and acid-base responses of rainbow trout to exhaustive exercise. I Exp Biol 194:299-317.

Kieffer J.D. and B.L. Tufts. 1998. Effects of food deprivation on white muscle energy reserves in rainbow trout (Oncorhynchus mykiss): the relationships with body size and temperature. Fish Physiol Biochem 19:239-245.

Kieffer J.D., A.M. Wakefield, and M.K. Litvak. 2001. Juvenile sturgeon exhibit reduced physiological responses to exercise. L Exp Biol 204:4281-4289.

Lankford S.E., T.E. Adams, and J.J. Cech Jr. 2003. Time of day and water temperature modify the physiological stress response in green sturgeon, Acipenser medirostris. Comp Biochem Physiol 135A:291-302.

Leonard J.B.K. and S.D. McCormick. 1999. The effect of migration distance and timing on metabolic enzyme activity in an anadromous clupeid, the American shad (Alosa sapidissima). Fish Physiol Biochem 20:163-179.

Lowry O.H. and J.V. Passonneau. 1972. A Flexible System of Enzymatic Analysis. Academic Press, New York.

Maxime V., G. Nonnote, C. Peyraud, P. Williot, and J.P. Truchet. 1995. Circulatory and respiratory effects of an hypoxic stress in Siberian sturgeon. Respir Phvsiol 100:203-212.

Maxime V., K. Pichavant, G. Boeuf, and G. Nonnotte. 2000. Effects of hypoxia on respiratory physiology of turbot, Scophthalmus maximus. Fish Physiol Biochem 22:51-59.

McDonald D.G. and C.L. Milligan. 1992. Chemical properties of the blood. Pp. 55-133 in W.S. Hoar, D.J. Randall, and A.P. Farrell, eds. Fish Physiology. Academic Press, New York. McKenzie D.J., G. Piraccini, N. Papini, C. Galli, P. Bronzi, C.G. Bolis, and E.W. Taylor. 1997. Oxygen consumption and ventilatory reflex responses are influenced by dietary lipids in sturgeon. Fish Physiol Biochem 16:365-379.

McKenzie D.J., G. Piraccini, J.F. Steffensen, C.L. Bolis, P. Bronzi, and E.W. Taylor. 1995. Effects of diet on spontaneous lo- comotor activity and oxygen consumption in Adriatic sturgeon (Acipenser naccarii). Fish Physiol Biochem 14:341-355.

Mommsen T., M. Vijayan, and T. Moon. 1999. Cortisol in teleosts: dynamics, mechanisms of action and metabolic regulation. Rev Fish Biol Fish 9:211-268.

Nonnotte G., V. Maxime, J.P. Truchet, P. Williot, and C. Peyraud. 1993. Respiratory responses to progressive ambient hypoxia in the sturgeon, Acipenser baeri. Respir Physiol 91: 71-82.

Parsons G.R. and J.K. Carlson. 1998. Physiological and behavioral responses to hypoxia in the bonnethead shark, Sphyrna tiburo: routine swimming and respiratory regulation. Fish Physiol Biochem 19:189-196.

Perry S.F. and K.M. Gilmour. 1999. Respiratory and cardiovascular systems during stress. Pp. 52-107 in P.H.M. Balm, ed. Stress Physiology in Animals. Academic Press, Sheffield.

Perry S.F. and S.G. Reid. 1994. The effects of acclimation temperature on the dynamics of catecholamine release during acute hypoxia in the rainbow trout Oncorhynchus mykiss. I Exp Biol 186:289-307.

Salama A. and M. Nikinmaa. 1989. Species differences in the adrenergic responses of fish red cells: studies on whitefish, pikeperch, trout and carp. Fish Physiol Biochem 6:167-173.

Secor D.H. and T.E. Gunderson. 1998. Effects of hypoxia and temperature on survival, growth, and respiration of juvenile Atlantic sturgeon, Acipenser oxyrinchus. Fish Bull 96:603613.

Steffensen J.F., J.P. Lomholt, and K. Johansen. 1982. Gill ventilation and $\mathrm{O}_{2}$ extraction during graded hypoxia in two ecologically distinct species of flatfish, the flounder (Platichthys flesus) and the plaice (Pleuronectes platessa). Environ Biol Fish 7:157-163.

Wilkie M.P., M.A. Brobbel, K. Davidson, L. Forsyth, and B.L. Tufts. 1997. Influences of temperature upon the post-exercise physiology of Atlantic salmon (Salmo salar). Can J Fish Aquat Sci 54:503-511.

Winer B.J. 1971. Statistical Principles in Experimental Design. McGraw-Hill, New York.

Zar J.H. 1999. Biostatistical Analysis. 4th ed. Prentice Hall, Upper Saddle River, NJ. 